\title{
Pályázati felhívás az Egészségfejlesztés folyóirat szerzői számára 60 éves az Egészségfejlesztés folyóirat
}

\author{
Call for presentation
}

doi: 10.24365/ef.v60i4.512

Az Egészségfejlesztés folyóirat szerkesztősége a lap fennállásának 60. évfordulója alkalmából meghívja szerzőit, hogy pályázzanak a lapban a pályázat benyújtási határidejéig megjelent közleményükkel előadás megtartására. A nyertes cikkek szerzői a folyóirat jubileumi konferenciáján mutathatják be munkájukat.

\section{A pályázat fő célja:}

- Az írásban már megjelent, széleskörú szakmai érdeklődést kiváltó közlemények előadás formájában való bemutatása.

- Szélesebb nyilvánosság biztosítása az egészségfejlesztés területét érintő kutatási eredményeknek, gyakorlatoknak.

\section{Pályázati feltételek:}

- Az Egészségfejlesztés folyóiratban már megjelent eredeti, áttekintő és agora közleményekkel lehet pályázni.

- Egy szerző több közleménnyel is pályázhat, de csak egy előadást tarthat.

\section{Benyújtási határidő:}

A pályázatokat 2019. október 4-ig kell beküldeni a folyoirat@nnk.gov.hu e-mail címre.
Az anyagnak tartalmaznia kell az alábbiakat:

- A közlemény adatai: cím, szerző(k), megjelenés (évfolyam, szám), rovat.

- Rövid indoklás arról, hogy miért tartja a szerző fontosnak munkája bemutatását.

A pályázat elbírálása:

- A pályázatokat a rendezvény szakmai szervezőbizottsága bírálja el.

- A bírálat általános szempontja, hogy a céloknak és feltételeknek megfeleljen a pályázati anyag.

- A pályázatok közül a bírálat során 2 eredeti, 2 áttekintő és 2 agora közlemény kerül kiválasztásra.

A nyertes közleményeket a „60 éves az Egészségfejlesztés folyóirat" című jubileumi konferencián mutathatják be a szerzők egy 10 perces előadás formájában, továbbá megjelennek a lektorált konferencia absztrakt kötetben. A rendezvény Budapesten lesz, várhatóan 2019. december első felében. A pályázat eredményéről november elején kapnak értesítést a nyertes pályázók.

Kapcsolat:

A pályázattal kapcsolatosan további információ a folyoirat@nnk.gov.hu e-mail címen kérhető. 